УДК 456.31

\title{
FORMATION OF THE PAPAL POSSESSIONS IN ITALY AND ESTABLISHMENT OF THE PAPAL STATE
}

\author{
B. Hutiv \\ Ivan Franko National University of Lviv, \\ 1, Universytetska Str., Lviv, 79000, Ukraine, \\ e-mail: bokus2012@gmail.com
}

There has been investigated in the article the process of creation of the Papal States in Italy and their unification into the Pope's Patrimony (Patrimony of St. Peter), which preceded the formation of the Papal Empire. There have been considered the first legal acts, which recognized the Christians' freedom to worship, delegated the Church the authority to landed estate and settled the acknowledgment of political power of the Popes in the territories that belonged to them, namely: the Edict of Toleration by Galerius published at Nicomedia in 311, the Edict of Milan (313), Constitution of Constantine (321), Theodosian Code, in particular, its XVI book „On Universal or Catholic Church». There have been elucidated the peculiarities of obtaining land assets by the Church based on the above-mentioned legal acts as a result of donation or inheritance. The has been described the deed of gift of the King of the Lombards (Langobards) as of 728 as the first legal document, which gave in the possession of the Pope the whole city («The Donation of Sutri»). There has been analyzed the historical backgrounds and political and legal consequences as well as the historic significance of «The Donation of Pepin» -the donation of the king of Franks, an act effected in 754, when the Papal States was created de facto, confirmed in 756, which became its authorization within the limits of the Roman Province and the Exarchate of Ravenna. There have been revealed the falsehood of the Donation of Constantine diploma developed to prove «The Donation of Pepin».

Keywords: Papal landownership, Patrymoniy St. Peter, the Pope, «Pypin gift», «gift of Constantine».

The modern state of Vatican, renewed within its current area as an independent state in 1929 on the grounds of the Lateran Treaties between Mussolini and the Pope Pius XI, was preceded by the Papal Empire with its millennial history. In the Middle Ages, it was a powerful state occupying the major part of the Apennine Peninsula (Italian Peninsula) and existed up to 1870 , when the modern state of Italy was created. The Papal Empire arose as a result of incorporation of the states of the church in Italy into one region (therefore most of the sources of information provide both names State of the Church or Papal Empire) under the reign of the Pope as secular ruler. However, the first land properties of the Pope had started to develop some centuries before his own state was created. That is to say that in accordance with the catholic theological doctrine, the origin of the papal institution began upon the Apostle Peter the founder of the first Christian community in Rome after the Crucifixion. In 64 or 67 (unspecified by scholars [11, p. 10]), by order of emperor Nero, the Apostle Peter was also crucified, but upside down at his own request, since he saw himself unworthy to be crucified in the same way as his teacher Jesus. After the adoption of Christianity over the hypothetic tomb of Saint Peter in 324 A.D., the Roman emperor Constantine I built St. Peter's Basilica. The teaching saying that Jesus entrusted the power over the church to Peter (Now I say to you that you are Peter (which means 'rock'), and upon this rock, I will build My church, and all the powers of hell will not conquer it. I will give you the keys of the Kingdom of Heaven (Matthew 16:18)) and laid responsibility

(C) Hutiv B., 2017 
on him for the control over it and this power and responsibility would be inherited by Peter's successors - the Roman bishops [29] is known as the teaching about Peter's succession which appeared between the $2^{\text {nd }}$ and $3^{\text {rd }}$ centuries in the compositions Christian ideologists and received the final confirmation in the papal supremacy [12, p. 5] adopted at the First Vatican Council (1870).

The word «pope» originates from the Greek word «papas» («father»). Early Christians called like this their spiritual advisors, priests, and bishops. The term regarding the bishop was used for the first time by Tertullian in the $3^{\text {rd }}$ century. The Council of Serdica (in the years of 343-344) directly stated that «Rome is the chair of St. Peter and it should be addressed by all the bishops of any provinces». Since the $5^{\text {th }}$ century, when all the Roman bishops subordinated all the bishoprics of Italy to their influence, the name has existed in the church documents as a generally accepted title of the Roman bishop. In 1073, the Pope Gregory VII stated that the right to bear this title only belongs to the Roman bishop [12, c. 5].

Thus, the history of the modern state of Vatican has old historical beginnings and Vatican itself officially considers that the legal standing of the Holy See never stopped during two millennia.

It is difficult to overestimate the geopolitical influence of the Papal Empire on the world history. In the Middle Ages, it was a socio-political and diplomatic engine of the whole Europe.

The establishment of the Papal Empire was preceded by some hundreds of years of the existence of various Papal states both in Italy and abroad, namely, in Gaul, Africa, Asia etc. The appearance of these states, their legal consolidation, further extension of the papal states and power took place in the background of complex historical, social, political, legal, religious and cultural processes. First of all, it was required to recognize the Christian church by the Roman Empire, legalize its status as well as its acquisition of property rights including land rights, and recognize the right of ownership to the states. Upon that, the establishment and development of the officially recognized Roman church took place under conditions of its constant opposition represented by popes, who strove for the affirmation of full power on their own territories both regarding the Byzantine Empire and Germanic tribes of Langobards (Lombards).

The study of the peculiarities of the establishment and development of the Papal Empire was undertaken by many foreign and native scholars, such as the GermanAmerican historian Philip Schaff, German historian Ferdinand Gregorovius, American historian Thomas Woods, Polish historian Jan Wierusz Kowalski, Hungarian scholar Enio Gergei, Russian byzantiologist F. I. Uspenskiy, V. V. Bolotov, V. L. Zadvornyi, S. G. Lozynskiy, A. A. Krasikov, I. R. Grygulevich, R. T. Rashkova and Russian protoiereus V. Rozhkov and Ukrainian scholars V. M. Zayikyn, H. F. Khorunzhyy, D. V. Trofimov, L. O. Popsuyenko, D. V. Volovnykiv and others). Apart from that, this theme still retains its topicality, since the majority of Ukrainian scholars studied separate issues on legal standing, sovereignty, and legislation of the Papal Empire, and the foreign scholars focused more attention on the historical conditions and religious aspects of the formation and development of the Papal Empire. Therefore, I consider it necessary to stop, firstly, at the detailed consideration of legal and political preconditions of the appearance of papal states in Italy, that is to say, their incorporation into a unitary Papal Empire.

This research aims at ascertaining of historical, political and legal preconditions of formation of the Papal States in Italy as well as political peculiarities and legal arrangement of the establishment of the Papal Empire. To achieve this goal, it is 
necessary to solve the following tasks: to consider the first legal acts which entitled the Church to tenure (land ownership) and consolidated the recognition of power of the Popes on their territories, namely the edict of Toleration by Galerius (311), the Edict of Milan (313), Constitution of Constantine (321), Theodosian Code; to characterize the historical preconditions, political and legal consequences and the historic significance of «The Donation of Pepin»; and reveal the falsehood of «The Donation of Constantine.»

During the first three centuries, since the appearance of Christianity in the Roman Empire, Christians had been undergoing constant expulsions. At the same time, the edict of toleration by Galerius was adopted. The edict ceased any persecution of the Christians, the liability for which mainly laid on it [19, p. 10]. It can be considered as the first legislative act which marked the beginning of the legalization of the Christian Church [19, p. 11]. Shortly before his death, the Emperor Galerius being seriously ill (probably suffering from prostate cancer) in Nicomedia, on April 30, 311 issued a decree that allowed the Christians to freely exercise their religion, namely, to build churches and perform services on the condition that they would pray for the welfare and health of the emperor and state.

The main landmark in the history of Christianity is considered to be a year of 313 , when the emperors of western and eastern part of the Empire Constantine I the Great and Licinius issued an edict in Mediolanum (currently Milan). It entitled the Christianity to legal existence in the Roman Empire. The edict was dedicated to the Christians, Christian teaching of the faith and the conditions and circumstances of the Christian liturgical cult as well as the equality of all the religions and the freedom of belief, «Everyone is given the freedom to accept the belief which they think is good for them» [18, p. 328-329].

The edict of Milan regulates the property and social rights of the Christians, both common and personal, and foresees the return to the Christians their full ownership which was taken away from them during persecution. Upon this, great focus is made on the fact that the status of the owners of property does not matter. Actually, the legislators come out of the interests of the Christian church. The interests of non-Christians are given a secondary position. Thus, the Christians were not only returned their land and houses belonging to them. By virtue of kindness of the secular authority, they were also given the legal rights to all the property which had been used by them before. I will note that the Edict of Milan recognized the existence of a special kind of land ownership «one for the benefit of the church as a whole rather than for certain people» [18, p. 330].

Constantine continued his favorable policy for Christianity, and in 319 , he released the clergy from the municipal service (but not from the federal ones such as the construction of bridges and public roads [2, p. 510]) and the church from the tax on real estate. Thus, the church lands were still taxed. In 321, he provided the churches with the right to buy the real estate and possess it. He also provided all his subjects with the right to bequeath their property in favor of the church. Finally, in 324, Constantine declared Christianity the state religion of the Roman Empire [18, p. 330].

The most significant measure by Constantine in favor of Christianity is considered to be the order of the collection of some of the taxed land in favor of the local church, which laid the foundations of the economic power of the Church [18, p. 331].

Let me note that yet in the Edict of Milan the Christian community was defined by Constantine as a corpus christianorum. According to the civil law, such corporations enjoyed the right to acquire property: 1) by means of purchase, 2) by means of donation 3 ) under the will. The right for the church to acquire the property by means of purchase is doubtless. The right to acquire the property by means donation has been enjoyed by the church since 321 , though the status acquired by the church on the grounds of the Edict of 
Milan enabled it to enjoy this right. The special legislation of 321 on this issue concerns only its specification.

Obtaining the property by means of will in the Roman Law was more complicated than donations, since the lawyer Ulpian declared that it is impossible to appoint «unspecified people» as heirs (personae incertae) - the whole cities, all the citizens of the city, even the gods. Thus the church as a corporate entity could not receive the legacy. In order not to have the bequest cancelled, fidei commissum had to be exercised: the property was entrusted to one of the members of the church to conscientiously transfer it to the entire Christian community. Instead of this, Constantine the Great recognized by the Constitution as of 3 July 321 the right for the Church to receive a legacy. This law was not subjected to any further restriction [2, p. 498], «Let everyone have the right to remain any of their property they like [in the bequethal order] in case of death in favor of the most sacred catholic and venerated congregation of the [Church]» [4, p. 38].

Let me note that expressing patronage to the Christian church, Constantine remained a pagan all his life and was baptized just before his death. His patronage over the affairs of the Christian church can be regarded as part of the traditional imperial responsibilities [18, p. 332].

The Theodosian Code, which was made in the years of 435-438 during the reign of Theodosius II the Younger (408-450) - the Emperor of the Eastern Roman Empire, initiated the process of formation and arrangement of the legal status of the Church.

Namely the Theodosian Code was the main source of principles and legal norms that defined the character of the canon law. It is the first memorabilia of the laws in which religious issues are not only the subject of law-making, but also are separated in a group. All of them are collected in Book XVI titled «On the universal or catholic church» which contains the laws related to exclusively religious affairs. The Code states that the Christian church is the Church of Nicaea and it is part of the state apparatus, part of the state and the organization which can not be separated from the state, because the matter of worship, internal structure and hierarchy are solved by the emperor $[19, \mathrm{p} .9,11]$.

Book XVI is divided into 11 titles which contain the collection of 201 fragments of the imperial constitutions. The first title is devoted to the general issues of the Christian faith, the second title is devoted to Christian bishops and clergy. Nevertheless, many of the church issues are settled in other books of the Code. Well, Book V in Title 3 «On clerical monks» contains Law 434 pages on the issue if a cleric or monk died and didn't leave a bequest ( $\mathrm{ab}$ intestato) or direct heirs their property went in favor of the church [13].

Book XVI of the Theodosian Code also contains specific provisions of a material character regarding deprivation of heretics of their land possessions [1].

By virtue of the above-mentioned favorable laws for the Christian church, its land possessions grew so much that they occupied $1 / 10$ of the entire national territory [2, p. 499].

Despite the presence of many Christian communities on the territory of the Roman Empire, the Roman community became the leading one on the grounds of the fact that its founder was the Apostle Peter. Furthermore, since martyrs and Peter himself shed too much blood on the land of Rome, a kind of redemption of the city and its population which opposed Christianity for a long time had to become the consolidation of the Roman community as a stronghold of faith. Thus, the Roman Pope got overgrown with numerous lands in many different parts of Italy, especially those located in the outskirts of Rome and on the coasts of Sicily and were passed to him as a kind of offering to the Holy Church by all the volunteers who strove in such a way to insure the everlasting bliss in Heaven. Furthermore, farmers in need were obliged to convey their land allotment on the peccary conditions to the church for its support to 
them. After the death of the farmer the land allotment passed to the church for good $[15$, p. $8-9,29]$. So the origin of the Papal States began in the $I^{\text {th }}$ century, when the Roman church acquired as a result of donation and bequest of many wealthy Christians the large land estates scattered all over Italy, Gaul, Illyria, Dalmatia, Africa and Anatolia. Thus the Church gradually acquired the secular power, relying on their lands and their peasants, and the Pope became not only the ruler of the Church but also the secular ruler of the $\mathrm{VI}^{\text {th }}$ century. He began to control the actions of the secular authorities in Rome and his closest outskirts.

Since the times of the reign of Pope Gregory I the Great (590-604), the papacy has become the largest landowner in Italy and holds a relative independence from the Byzantine Empire, which in the person of exarchs (Exarchate - Byzantine province in Italy formed at the end of the $16^{\text {th }}$ century) had here weak and idle governors.

In the Roman Duchy which appeared at the end of the $\mathrm{VI}^{\text {th }}$ century and belonged to the Exarchate, as a result of a gradual loss of positions of the Byzantine power in Italy, the figure of the Pope eventually replaced the Duke appointed by the emperor. Moreover, the Popes also assumed the power of the exarch, especially in the performance of legal and appellate functions, collecting taxes, carrying out political and military relationships with neighboring rulers.

The first legal act that symbolizes the beginning of the recognition of secular power of the Popes and has essential political significance is considered to be the donation of Liutprand, the king of Germanic tribes called Lombards, given in 728 in the town of Sutra near Rome («Sutra gift»).

Taking advantage of the conflict between Pope Gregory II (715-731) and the Byzantine Emperor Leo III (717-741) on iconoclasm and the weakening of the Byzantine Empire, which has been subjected to threats from the Arabs, Persians and Slavs and the suffering of the palace upheavals and uprisings [5], the king of the Lombards Liutprand captured Ravenna, the cities of Emilia and Pentapolis and finally invaded the Roman Duchy. However, Pope Gregory II managed to persuade the king to retreat by means of gifts, pleading letters and skillful diplomatic approaches. Moreover, he not only left the Roman Duchy, but also gave what he conquered in the city of Sutra at the disposal of the Pope, who on behalf of the Apostle Peter presented his claim to him. This was the first case of donation transferred from the city to the church [7, p. 220-221]. So by this act, the Popes received the first-ever formal recognition of political power in their territories that belonged to the Byzantine governors.

However, in 751 the Lombards still took the Exarchate. Expecting the Lombard attack on Rome and staying at the time in hostile relations with the Byzantine emperor, due to the fact that because of the dispute of the veneration of Pope the Byzantine iconoclasts were condemned, Pope Stephen II (752-757) requested the third party, the Franks, for the armed protection. However, in the first half of the VIII ${ }^{\text {th }}$ century, the Frankish Mayor of the Palace Charles Martel, stopping the advancement of Arabs to Europe, encroached on the lands of the Church, so the relations between Frankish state and the Pope got complicated. And when the king of the Lombards Aistulf came to the walls of Rome, he demanded a tribute from Stephen II. So Stephen II was compelled to seek help from the Mayor Pepin III the Short who, in 751, was anointed by the Pope Zacharias for the King of the Franks [6, p. 63-65].

On 14 April 754 at the meeting in Querse near Paris, they made a decision to start a war against the Lombards. Therefore, the Donation of Pepin III by which he was obliged to return to the Pope Stephen II the lands taken away from the Byzantine Empire and the 
King of Lombards Aistulf was the next important document that affirmed the secular authorities of the pontiffs. This agreement which meant an alliance between the papacy and the Frankish feudal monarchy foresaw the military action against the Lombards and the forced return of the lands which belonged to the Exarchate and Roman Duchy before their invasion by the King Aistulf. From his side, the Pope Stephen II recognized Carolingians as legitimate kings of the Frankish state and solemnly consecrated the Carolingian dynasty, giving Pepin and his sons (including underage Charles the Great) the title of «The Patrician of Rome,» which was previously given only the governor of the Byzantine Emperor in Ravenna. Therefore, Pepin being the Roman patrician became a defender of the Roman Church [3, p. 14].

On 28 July 754, Stephen II made the ceremony of coronation and anointing of Pepin III in the Cathedral of Saint Denis. So he could not ignore the request of the church, and in 756, in response to the letter «miraculously written by St. Peter himself,» the army of the Franks entered Italy and defeated the Lombards who were forced to release the lands of the Roman Duchy and the Exarchate. These lands were returned to the Pope by the King of the Franks on the grounds of the prior agreement.

Thus, the «Donation of Pepin» to the Pope covered the Exarchate of Revenna (which included Venice and Istria), the cities of Ravenna and Pentapolis, a coastal strip of the 5 cities of Rimini, Pesaro, Fano, Ancona and Senegaglia as well as Parma, Reggio and Mantua, the Duchy of Spoleto and Benevento, the island of Corsica and Rome itself with its outskirts [20, p. 68]. Pepin ordered to put the keys to these cities on the tomb of St. Peter. It had to symbolize the transfer of the donation not to the Pope in person but to the Apostolic Church [20, p. 68].

Thus, the Pope was approved by Pepin as the head of an independent state which stretched over the Central Italy (with its center in Rome), and existed over a thousand years. In the history, these events are called «The Donation of Pepin» as an act performed in 754, when the Papal State was established de facto and confirmed in 756. It became its sanctioning.

Since the originals and copies of «The Donation of Pepin were lost, in a short run they made a fake diploma «The Donation of Constantine» on the purpose of providing more legitimacy to this agreement. According to this diploma, in the IV century the Emperor Constantine passed under the authority of the Roman bishop Sylvester I (in appreciation for healing him of his leprosy after baptism) Rome region and the whole Italy, making him his governor over the whole western part of the empire. The falsehood of the ratification was proved in the $15^{\text {th }}$ century by Lorenzo Valla.

In his treatise «On falsehood of the»Donation of Constantine»») in 1440, he first of all found out that the transfer of authority by Constantine over Western Empire to Pope was not mentioned in any significant monuments to the past. Such an act would be contrary to all the laws and customs of the Roman Empire and the most common sense. The most important thing is that, the language of the act of «donation» was completely out of character of the Classical Latin of the IV century. Based on these grounds made by L.Valli, Papal throne until the XIX century followed the position that the document "Constantine gift» is a falsehood, however the act of donation itself occurred at the time. Just in the XIX century in the official church publications there was recognized as the falsehood both the document itself and the event described in it [6, p. 67-68].

The theological doctrine of the succession of Peter argues that the governors of the Apostle, whom Christ himself entrusted power over the church, are the Roman bishops. Therefore, since the $\mathrm{V}^{\text {th }}$ century the Popes subjected to their influence all the episcopate 
of Italy. At the same time, since the IV century they began actively acquiring and expanding their landed estate. It was favoured by the cease of persecution of Christians in the Roman Empire, which was firstly consolidated in the Edict of toleration by Galerius published in Nicomedia in 311, which terminated any persecutions of Christians, legalized Christianity and allowed the performance of ceremonies under conditions that Christians would pray for the welfare of state and the emperor.

The continuation of the edict was the edict of Milan 313, which set a new direction of religious policy of the Roman Empire. All the religions obtained equal rights, in other words the traditional Roman paganism was losing its role of the official religion, the Christian church was recognized as such that has the rights of the legal entity. He laid the beginning of recognition of the Christian church as a religious organization and consolidation of its legal status. The edict anticipated the returning to Christians and Christian communities all the property that was taken away from them during the persecution.

The Constitution of Constantine 321, gave the churches a right to buy immovable property and own it, and all the subjects were entitled to bequeath their property in favor of the church, which was the main impulse for the expansion of the Papal States. Finally, in 324. Constantine declared Christianity the state religion of the Roman Empire.

Before the registration of the XVI-th book of the Theodosian Code «On universal or catholic the church», the issues related to religion, not only were not the object of an independent law-making, but also were never considered apart from the domestic political, economic, situation etc. Book XVI of the Code includes the Constitution of the emperors, committed to the Christian faith and Christians who perpetuate the domination of the Christian church, containing, in particular, the provisions on limitation of heretics in their property rights and even depriving heretics of their land holdings in favor of the Catholic Church (Constitution 407, 412 and 426). That undoubtedly contributed to an even greater expansion of papal states in Italy and in remote areas (Africa, Asia, etc.)

However, the numerous parcels of land acquired by the church based on the considered legal acts of donation and succession, were united in the Pope's Patrimony, (St. Peter's Patrimony), which during the reign of Pope Gregory I the Great (590-604) had a relative independence from the Byzantine Empire.

The first legal act, which for the first time assigned to the Pope the whole city, subject to the secular authorities, not to the Byzantine Exarch and Duke, was the Donation of the king of Germanic tribes Lombards Liutpranda, published in $728 \mathrm{~g}$. in the town of Sutra not far from Rome («Sutra gift»). Later on, the Pope, taking an advantage of the crisis in the Byzantine Empire and with direct assistance of Franks in opposition to Lombard, managed to create an independent state within the Roman area and Exarchate. The final step in the legal registration of independent Papal States was the «Donation of Pepin» - an act committed in 754, when the Papal State was established de facto and confirmed in 756, which became its sanctioning, which was confirmed by falsified diploma «Constantine gift».

In such a way, under the conditions of collapse of Western Roman Empire, the rapid formation and the same rapid collapse of «barbaric» kingdoms, constant cutting out of borders, feudal factionalism the Church was the most organized force, that made managed to gain and expand the Papal states within several centuries both in Italy and abroad, and finally create their own Papal Empire, which lasted until 1870. The peculiarities of its formation and development will be the subject of my further research.

\section{Список використаних джерел}

1. Астапенко П. Н. Нормативно-правовые основы деятельности религиозных конфессий в римском праве постклассического пери ода. URL: http://kenoma.chat.ru/gnost/theod.htm 
2. Болотов В. Лекции по истории Древней Церкви: Посмертн. изд. / под ред. [и с предисл.] проф. А. Бриллиантова. Санкт-Петербург: Тип. Меркушева, 1907.

3. Воловників Д. В. Аспекти становлення ідеології ранньої Папської держави (випадок «дарчої грамоти імператора Костянтина») // Науковий вісник Дипломатичної академії України. Серія «Зовнішня політика і дипломатія: традиції, тренди, досвід». Київ, 2013. Вип. 20(1). С. 113-118.

4. Второй титул шестнадцатой книги Кодекса Феодосия. Перевод, краткий историкоправовой комментарий Е. В. Сильвестровой // Вестник ПСТГУ I: Богословие. Философия. 2010. Вып. 2 (30). С. 34-64.

5. Вудс Т. Как Католическая церковь создала западную цивилизацию / пер. с англ. В. Кошкина. Москва: ИРИСЭН, Мысль, 2010. 280 с.

6. Гергей Е. История папства / пер. с венг. Москва: Республика, 1996.

7. Грегоровиус Ф. История города Рима в Средние века (от V до XVI столетия). Полное издание в одном томе / пер. В. И. Савина. Москва: Издательство АЛЬФА-КНИГА, 2008. 1058 c.

8. Грант М. Римские императоры: Биографический справочник правителей Римской империи 31 г. до н. э.- 476 г. н. э. / пер. с англ. М. Гитт. Москва: ТЕРРА-Книжный клуб, 1998. 400 с.

9. Григулевич И. Р. Папство. Век ХХ. 3-е изд., испр., доп. Москва: Терра, 2003.

10. Евсевий Памфил. Церковная история: в 10 книгах // Богословские труды. Московский патриархат. Москва, 1982-1985. Сб. 23-25. [репр.: М.: Изд. Спасо-Преображенского Валаамского монастыря, 1993].

11. Задворный В. Л. История Римских Пап. Т. І. От св. Петра до св. Симплиция. Москва: Колледж католической теологии им. св. Фомы Аквинского в Москве, 1995. 349 с.

12. Ковальский Я. В. Папы и папство. Москва, 1991.

13. Кодекс Феодосия и Новеллы императоров Валентиниана III, Майориана и Либия Севера о колонах, сельских рабах и вольноотпущенниках. Перевод А. Копте ва сделан по изданию: Theodosiani libri XVI cumconstitutionibus sirmonlianis et leges novellaead Theodosianum pertinentes / Ed. Th. Mommsen et P. Meyer. Berolini, 1905. Vol. I-II.

14. Красиков А. А. Ватикан: история и современность. Москва: Знание, 1991. С. Г. Лозинский. 3-е изд. Москва: Политиздат, 1986. 382 с.

15. Первый титул шестнадцатой книги Кодекса Феодосия. Вводная статья, перевод, краткий историко-правовой комментарий Е. В. Сильвестровой // Вестник Православного Свято-Тихоновского гуманитарного университета. Серия 1: Богословие. Философия. Религиоведение. Вып. 2 (26). 2009. С. 7.

16. Попсуєнко Л. О. Значення Кодексу Феодосія для формування канонічного права // Актуальні проблеми держави і права: зб. наук. праць. Вип. 25. Одеса: Юрид. л-ра, 2005. C. 289-292.

17. Попсуєнко Л. О. Міланський едикт 313 р. - юридичне підгрунтя в процесі формування правового статусу християнської церкви // Актуальні проблеми політики: збірник наукових праць / керівник авт. кол. С. В. Ківалов; відп. за вип. Л. І. Кормич. Одеса: Фенікс, 2009. Вип. 36. С. 327-334.

18. Попсуєнко Л. О. Правовий статус християнської церкви за римським імператорським законодавством IV сторіччя: автореф. на здобуття наук. ступеня канд. юрид. наук. Одеса: Одеська національна юридична академія, 2006. 20 с.

19. Рашкова Р. Т. Католицизм. Санкт-Петербург., 2007. 240 с.

20. Римское право и общество / за ред. П. Н. Астапенко ; пер., комм. Москва, 2005. Ч. 2. C. 287-296. 


\section{References}

1. Astapenko, P. N. Normativno-pravovye osnovy deyatelnosti religioznykh konfessiy v rimskom prave postklassicheskogo perioda. Retrieved from http://kenoma.chat.ru/gnost/theod.htm

2. Bolotov, V. (1907). Lektsii po istorii Drevney Tserkvi: Posmertn. izd. Sankt Peterbyrg: Typ. Merkusheva.

3. Volovnykiv, D. V. (2013). Aspekty stanovlennya ideolohiyi rannoyi Papskoyi derzhavy (vypadok «darchoyi hramoty imperatora Kostyantyna»). Naukovyy visnyk Dyplomatychnoyi akademiyi Ukrayiny. Seriya "Zovnishnya polityka i dyplomatiya: tradytsiyi, trendy, dosvid», 20(1), 113-118.

4. Silvestrovoy, E. V. (2010). Vtoroy titul shestnadtsatoy knigi Kodeksa Feodosiya. Perevod, kratkiy istoriko-pravovoy kommentariy. Vestnik PSTHU I: Bogoslovye. Filosofiya, 2 (30), 34-64.

5. Vuds, T. (2010). Kak Katolicheskaya tserkov sozdala zapadnuyu tsivilizatsiyu. Moskov: IRISEN, Mysl.

6. Gergey, Y. (1996). Istoriia papstva (Per. s vengh.). Moskov: Respublika.

7. Gregorovius Ferdinand (2008). Istoriya goroda Rima v Srednie veka (ot V do XVI stoletiya). Polnoe izdanie v odnom tome. Per. V. I. Savina. Moskov: Izdatelstvo ALFA-KNIGA.

8. Grant, M. (1998). Rimskie imperatory: Biograficheskiy spravochnik praviteley Rimskoy imperii 31 g. do n. é. -476 g. n. é. Per. s angl. M. Gitt. Moskov: TERRA-Knizhnyy klub.

9. Grigulevich, I. R. (2003). Papstvo. Vek XX. 3-e izd., ispr., dop. Moskov: Terra.

10. Evseviy Pamfil. (1993). Tserkovnaya istoriya. V 10 knigakh. Bogoslovskie trudy. Moskovskiy patriarkhat. Moskov, 1982-1985. Sb. 23-25. [repr.: Moskov: Izd. Spaso-Preobrazhenskogo Valaamskogho monastyrya].

11. Zadvornyy, V. L. (1995). Istoriya Rimskikh Pap. Tom I. Ot sv. Petra do sv. Simplitsiya. Moskov: Kolledzh katolicheskoy teologii im. sv. Fomy Akvinskogo v Moskve.

12. Kovalskiy, Y. V. (1995). Papy i papstvo. Moskov.

13. Kodeks Feodosiya i Novelly imperatorov Valentiniana III, Mayoriana i Libiya Severa o kolonakh, selskikh rabakh i volnootpushchennikakh. (1905). Perevod A. Kopteva sdelan po izdaniyu: Theodosiani libri XVI cum constitutionibus sirmonlianis et leges novellae ad Theodosianum pertinentes. Ed. Th. Mommsen et P. Meyer. Berolini, I-II.

14. Krasikov, A. A. (1991). Vatikan: istoriya i sovremennost. Moskov: Znanie.

15. Lozinskiy, S. G. (1986). Istoriya papstva. 3-e izd. Moskov: Politizdat.

16. Silvestrovoy, E. V. (2009). Pervyy titul shestnadtsatoy knigi Kodeksa Feodosiya. Vvodnaya statya, perevod, kratkiy istoriko-pravovoy kommentariy. Vestnik Pravoslavnogo Svyato-Tikhonovskogo gumanitarnogo universiteta. Seriya 1: Bogoslovie. Filosofiya. Religiovedenie, 2 (26), 7.

17. Popsuyenko, L. O. (2005). Znachennya Kodeksu Feodosiya dlya formuvannya kanonichnoho prava. Aktualni problemy derzhavy i prava: Zb. nauk. prats, 25, 289-292.

18. Popsuyenko, L. O. (2009). Milanskyy edykt 313 r. - yurydychne pidgruntya v protsesi formuvannya pravovoho statusu khrystyyanskoyi tserkvy. Aktualni problemy polityky: Zbirnyk naukovykh prats / Kerivnyk avt. kol. S. V. Kivalov; vidp. za vyp. L. I. Kormych, 36, 327-334.

19. Popsuyenko, L. O. (2006). Pravovyy status khrystyyanskoyi tserkvy za rymskym imperatorskym zakonodavstvom IV storichchya. Avtoreferat na zdobuttya naukovoho stupenya kandydata yurydychnykh nauk. Odesa: Odeska natsionalna yurydychna akademiya, 20.

20. Rashkova, R. T. (2007). Katolitsyzm. Sankt Peterbyrg.

21. Astapenko, P. N. (Ed.) (2005). Rimskoe pravo i obshchestvo. Per., komm. Ch. 2. Moskov. 


\title{
УТВОРЕННЯ ПАПСЬКИХ ВОЛОДІНЬ В ІТАЛІЇ
} ТА ЗАСНУВАННЯ ПАПСЬКОӤ ДЕРЖАВИ

\author{
Б. Гуmiв \\ Львівський національний університет імені Івана Франка, \\ вул. Університетська, 1, Львів, Україна, 79000, \\ e-mail:bokus2012@gmail.com
}

Досліджено процес утворення папських володінь в Італії та об`єднання їх у Папську вотчину (Патримоній св. Петра), що передувало заснуванню Папської держави. Розглянуто перші юридичні акти, які визнавали свободу віросповідання християн, надавали Церкві право на землеволодіння та закріплювали визнання політичної влади Римських пап на належних їм територіях. А саме: Нікомедійський едикт Галерія 311 року, який припинив переслідування християн, дозволивши їм вільно сповідувати свою релігію, зокрема будувати церкви і проводити служби, за умови, що вони будуть молитися за благополуччя імператора і держави. Міланський едикт 313 року надав християнству право легального існування у Римській імперії, встановив рівноправність усіх релігій і свободу віросповідування, та передбачив повернення християнам усієї власності, яка була у них відібрана під час переслідувань. Конституція Константина 321 року надала церквам право купувати нерухоме майно і володіти ним, а усім своїм підданим право заповідати своє майно на користь церкви. Кодекс Феодосія, що був складений у 435-438 роках, започаткував процес формування та оформлення правового статусу церкви. Виявлено, що Кодекс Феодосія містить закон 434 року про те, що майно духовенства за відсутності заповіту (ab intestato) і прямих спадкоємців передається церкві. Встановлено, що XVI книга даного Кодексу «Про універсальну або католицьку церкву» закріплює заборону єретикам щодо дарування і заповідання ними майна, та передбачає позбавлення єретиків їхніх землеволодінь.

Висвітлено особливості набуття церквою на підставі даних правових актів землеволодінь внаслідок дарування і успадкування. З'ясовано, що поняття Патримонію св. Петра означало, що майно, отримане Папою у володіння, передається Петру як першому єпископу, а не цьому Папі, який виступає лише його наступником і як такий управляє цим майном. Простежено, що вже з часів правління папи Григорія I Великого (590-604) папство стало найбільшим в Італії землевласником та володіло відносною незалежністю від Візантійської імперії.

Охарактеризовано дарчу короля лангобардів 728 року як перший правовий документ, який надав папі Римському у світське управління окреме місто («дар Сутрі»). Проаналізовано історичні передумови та політико-правові наслідки й історичне значення дарчої короля франків - «дару Пипіна» - як акту, здійсненого 754 року, коли Папська держава була утворена де-фракто, та підтвердженого 756 року, що стало ії санкціонуванням у межах Римської області та Равеннського екзархату. Розкрито сфральсифікованість розробленої для обґрунтування «дару Пипіна» грамоти «Константинів дар».

Ключові слова: землеволодіння пап, Патримоній св. Петра, папа Римський, «дар Пипіна», «Константинів дар». 